\title{
APLIKASI TEKNOLOGI M-BIO UNTUK PEMBUATAN TEPUNG MOCAF (MODIFIED CASSAVA FLOUR) \\ DAN ANEKA OLAHANNYA SEBAGAI UPAYA PEMBERDAYAAN MASYARAKAT PADA MASA PANDEMI COVID-19 DI DESA SETIAWARAS KABUPATEN TASIKMALAYA
}

\author{
${ }^{1}$ Rudi Priyadi, ${ }^{1}$ Yaya Sunarya, ${ }^{1}$ Ade Hilman Juhaeni, ${ }^{2}$ Soni Tantan Tandiana, ${ }^{3}$ Ceceng \\ Saepulmilah \\ ${ }^{1}$ Program Studi Agroteknologi, Fakultas Pertanian Universitas Siliwangi \\ ${ }^{2}$ Program Studi Pendidikan Bahasa Inggris Fakultas Keguruan dan IImu Pendidikan Universitas Siliwangi \\ ${ }^{3}$ Program Studi Teknik Sipil, Fakultas Teknik Universitas Siliwangi \\ Corresponding author : Ade Hilman Juhaeni \\ E-mail : adehilman@unsil.ac.id
}

\begin{abstract}
ABSTRAK
Desa Setiawaras memiliki potensi singkong yang melimpah, namun sampai dengan saat ini masyarakatnya belum memanfaatkan potensi singkong tersebut secara optimal. Hal ini disebabkan karena harga singkong relatif rendah/murah dan dirasa kurang menguntungkan. Ditambah lagi dengan motivasi dan pengetahuan masyarakat untuk mengolah singkong agar nilai tambahnya meningkat masih rendah. Salah satu alternatif pengolahan singkong yang potensial yaitu pemanfaatan singkong menjadi tepung mocaf dengan bantuan teknologi M-Bio. Tujuan pengabdian masyarakat yaitu memanfaatkan potensi singkong untuk dijadikan tepung mocaf dan produk olahan makanan yang bernilai jual tinggi. Metode yang digunakan dalam pengabdian pada masyarakat ini yaitu : sosialisasi, penyuluhan, pengadaan alat penunjang, pelatihan dan praktek, serta evaluasi, sedangkan kelompok sasaran adalah Kelompok Tani Insan Mandiri dan Kelompok Pemberdayaan Kesejahteraan Keluarga (PKK) Desa Setiawaras Kecamatan Cibalong Kabupaten Tasikmalaya. Hasil pengabdian masyarakat melalui pemberdayaan masyarakat ini diharapkan dapat meningkatkan minat dan keterampilan masyarakat agar bisa memproduksi tepung mocaf, membuat aneka olahan makanan dengan bahan dasar tepung mocaf dan adanya peningkatan pendapatan masyarakat pada masa pandemi covid-19.
\end{abstract}

Kata Kunci: Mocaf, M-Bio, Pemberdayaan Masyarakat

\begin{abstract}
Setiawaras Village has potential abundance of cassava. However, the community has not utilized the potential of cassava optimally until these days. This is caused by the price of cassava is relatively low/cheap and considered to be less profitable. Besides, the community still has lack of motivation and knowledge in cultivating and increasing the value of cassava. One of the potential alternatives to cultivate the cassava is the utilization of cassava into mocaf flour with the help of M-Bio technology. The purpose of community service is to utilize the potential of cassava to be used as mocaf flour and produce food products that are profitable. The methods used in this community service are: socialization, counseling, procurement of supporting tools, training and practice, evaluation, while the target groups are the Independent Insan Farmer Group and the Family Welfare Empowerment Group (PKK) Setiawaras Village, Cibalong District, Tasikmalaya Regency. The results of community service through community empowerment are expected to increase the interest and skills of the community so that they can produce mocaf flour, make various foods with the basic ingredients of mocaf flour and increase community income during the covid-19 pandemic.
\end{abstract}

Keywords: Mocaf, M-Bio, Community Empowerment

\section{PENDAHULUAN}

Pemanfaatan tepung berbahan baku singkong atau sering dikenal tepung singkong masih rendah. Hal ini dikarenakan masyarakat Indonesia terbiasa mengkonsumsi tepung berbahan baku gandum (tepung terigu). Gandum merupakan bahan baku tepung yang berkualitas tinggi dari segi fisik. Produk yang dihasilkan dari bahan baku tersebut laris di pasaran, seperti mie instan, kue, makanan ringan. Tingginya konsumsi tepung terigu di Indonesia tidak dapat dipenuhi oleh petani Indonesia karena tanah Indonesia tidak dapat ditanami gandum. Tepung terigu yang sering dikonsumsi masyarakat Indonesia merupakan hasil impor dari negara tetangga. Berdasarkan 
data dari Assosiasi Produsen Tepung Terigu Indonesia (APTINDO), volume impor gandum pada tahun 2013 mencapai 6,37 juta ton, pada tahun 2014 meningkat menjadi 7,43 juta, dan menurun $-0,3$ persen pada tahun 2015. Akan tetapi, Januari tahun 2016 kembali meningkat sekitar 3,8 persen. Pengekspor gandum terbesar adalah Australia dengan total impor gandum mencapai 4,4 juta ton dengan nilai USD1,5 miliar. Pemenuhan kebutuhan gandum dalam negeri selain diperoleh dari Australia, juga Amerika Serikat, dan Kanada (Welirang, 2011)

Kebiasaan atau ketergantungan masyarakat terhadap tepung terigu perlu segera dicarikan solusi melalui diversifikasi pangan. Diversifikasi pangan yaitu pengembangan dan penggunaan sumber daya lokal sebagai pensubstitusi terigu. Salah satunya yaitu pemanfaatan singkong atau ubi kayu. Singkong merupakan sumber energi, vitamin dan mineral. Singkong mudah diperoleh di daerah negara tropis seperti Indonesia. Singkong dapat dijadikan sumber karbohidrat terbesar ke 4 setelah beras, jagung, dan tebu (Kusumayanti, et al., 2015)

Kadar pati pada mocaf lebih tinggi dibandingkan dengan tepung terigu, sedangkan kadar air yang terdapat pada mocaf lebih rendah sehingga menyebabkan lebih tahan terhadap pertumbuhan mikroba yang dapat menyebabkan kerusakan produk (Putri, et al., 2015). Mocaf juga memiliki karakteristik fisik kimia sebagai berikut, kadar pati $75.49 \%$; kadar air $11.04 \%$; protein $2.45 \%$; HCN 0 ppm; kadar lemak $0.73 \%$; dan kadar abu $1.95 \%$ (Amanu dan Susanto, 2014). Tepung mocaf adalah tepung singkong yang secara ekonomis ternyata jauh lebih murah daripada produk terigu yang selama ini beredar di pasaran. Akan tetapi Mocaf memiliki kandungan protein yang rendah, sehingga sifat fisiokimia yang belum sempurna sehingga perlu dilakukan pencampuran dengan tepung gandum (Rosmeri dan Monica, 2013). Oleh karena itu, mocaf merupakan produk tepung dari ubi kayu yang memiliki kadar pati lebih tinggi dibandingkan dengan tepung terigu dan kadar air yang rendah sehingga menyebabkan lebih tahan terhadap pertumbuhan mikroba dan secara ekonomis ternyata jauh lebih murah daripada produk terigu, serta tepung mocaf dapat dicampurkan dengan tepung gandum untuk memiliki kandungan protein yang lebih banyak.

Hasil penelitian Jensen, et al (2015), menunjukkan bahwa tepung berbahan baku singkong memiliki potensi besar sebagai alternatif yang lebih ekonomis dan berkelanjutan untuk menggantikan tepung terigu dalam produksi roti di Amerika Latin. Tepung terigu bisa diganti hingga 30\% tanpa perbedaan yang signifikan dari roti kontrol. Menurut Heny Kusumayanti tepung singkong memiliki kemampuan pengembangan lebih tinggi dari pada tepung kentang yaitu 13:3. Akan tetapi, produk bakeri hasil olahan tepung singkong belum dapat mengembang dengan baik seperti tepung terigu, hal ini dikarenakan tepung singkong tidak mengandung gluten. Modifikasi tepung singkong secara fisik maupun kimia diperlukan agar tepung memiliki kemampuan mengembang yang tinggi seperti tepung terigu.

Beberapa penelitian sebelumnya menyebutkan bahwa tepung singkong dapat dimodifikasi secara kimiawi dengan cara fermentasi. Cara fermentasi ini telah diterapkan di Afrika oleh Obadina dalam pembuatan produk Fufu, Lafun, dan Gari dengan bantuan bakteri Bacillus spp., Lactobacillus sp., Geotrichum spp., dan Aspergillus spp (Obadina, et al., 2009). Produk tepung berbahan baku singkong yang sedang dikembangkan di Indonesia adalah Tepung Singkong Termodifikasi atau Modified Cassava Flour (MOCAF). MOCAF adalah produk tepung dari fermentasi singkong (Manihot Asculenta Crantz) yang diproses menggunakan prinsip memodifikasi sel singkong dengan cara fermentasi aerobik sehingga menyebabkan perubahan karakteristik terutama berupa naiknya viskositas (daya rekat), kemampuan gelatinasi, daya rehidrasi, dan solubiliti (kemampuan melarut).

Salah satu produk unggulan hasil inovasi Fakultas Pertanian Universitas Siliwangi adalah Mix Culture dengan merk dagang M-Bio. Hasil analisis laboratorium terhadap kandungan bakteri/mikroba menunjukan bahwa M-Bio mengandung Lactobacillus $\mathrm{sp}$ dengan demikian dapat digunakan sebagai fermentor dalam pembuatan tepung MOCAF. Ujicoba yang dilakukan oleh mahasiswa dan dosen menunjukkan bahwa pembuatan Tepung MOCAF dengan menggunakan fermentor $\mathrm{M}$ Bio, memerlukan waktu singkat. Selain itu tepung MOCAF yang dihasilkan memiliki karakteristik mirip seperti terigu, yaitu putih, lembut, dan tidak berbau singkong serta hasil uji laboratorium menunjukkan bahwa kandungan proteinnya cukup tinggi.

Selanjutnya ujicoba oleh masyarakat dilakukan oleh Kelompok Wanita Tani di daerah Pati, Jawa Tengah dengan bimbingan dosen Fakultas Pertanian Universitas Siliwangi. Dan saat ini kelompok wanita 
tersebut telah mampu memproduksi MOCAF pada skala industri rumah tangga untuk menyuplai kebutuhan salah satu pabrik makanan ringan ternama ( mensubtitusi sebagian tepung terigu).

Sementara itu terdapat Desa Setiawaras Kecamatan Cibalong yang terletak $30 \mathrm{~km}$ dari ibukota Kabupaten Tasikmalaya. Secara umum bahwa Desa Setiawaras memiliki potensi yang sama dengan daerah Pati yakni sama-sama penghasil singkong. Namun sampai dengan saat ini masyarakat belum memanfaatkan potensi singkong tersebut secara optimal. Hal ini disebabkan karena harga singkong relatif rendah/murah dan dirasa kurang menguntungkan. Ditambah lagi dengan motivasi dan pengetahuan masyarakat untuk mengolah singkong (agar nilai tambahnya meningkat) masih rendah. Berdasarkan uraian tersebut diatas, maka perlu dilakukan pemberdayaan masyarakat melalui : sosialisasi, penyuluhan, pelatihan dan pembinaan serta monitoring dan evaluasi dalam pemanfatan singkong menjadi tepung mocaf dan aneka olahannya menjadi beraneka ragam makanan.

\section{METODE}

Metode pelaksanaan pengabdiian masayarakat ini yaitu meliputi kegiatan sosialisasi dan pelatihan aplikasi teknologi tepat guna.

\subsection{Sosialisasi}

Sosialisasi dilaksanakan di Desa Setiawaras dengan tujuan untuk memberikan gambaran mengenai peluang pengembangan usaha pengolahan singkong menjadi tepung Mocaf dan pengembangan Agroindustri olahan tepung mocaf.

\subsection{Penyuluhan}

Penyuluhan pengolahan singkong menjadi tepung mocaf ini dilakukan melalu metode ceramah dan diskusi. Peserta penyuluhan adalah anggota Kelompok Tani Insan Mandiri yang berjumlah 15 orang dan Kelompok Pemberdayaan Kesejahteraan Keluarga (PKK) yang berjumalah 15 orang, sehingga total peserta berjumlah 30 orang. Para peserta diberikan materi dalam bentuk modul yang dibagikan. Materi yang disampaikan yaitu cara pembuatan tepung mocaf dengan aplikasi M-Bio, teknis penggunaan mesin tepung dan cara

\section{HASIL DAN PEMBAHASAN}

Ketela pohon atau singkong merupakan sumber karbohidrat yang sudah cukup lama dikenal masyarakat, saat beras pengolahan aneka makanan berbahan tepung mocaf.

\subsection{Pengadaaan alat penunjang}

Kegiatan PPM ini dilakukan berupa pelatihan keterampilan pengolahan singkong menjadi tepung mocaf dan aneka olahannya. Maka langkah yang dilakukan dalam pembuatan tepung mocaf yaitu berupa pengadaan alat untuk membuat tepung mocaf yaitu mesin perajang singkong, penggilingan tepung dan alat perekat plastik (impulse sealer). Sedangkan untuk pembuatan aneka olahan makanannya menggunakan alat-alat dapur seperti biasanya.

\subsection{Pelatihan dan praktek}

Kegiatan ini menggunakan metode demonstrasi. Metode demonstrasi diperlukan untuk memberi pengetahuan, pengalaman, pemahaman, dan contoh kepada kelompok tani desa Setiawaras. Penggunaan metode demonstrasi ini untuk memberikan contoh praktis dalam hal pembuatan tepung mocaf , teknik mengoperasikan mesin perajangan, penggilingan tepung, dan alat perekat plastik (impulse sealer) dan cara menjaga keselamatan dan kesehatan kerja. Keselamatan dan kesehatan kerja dapat ditinjau dari keamanan mesin yang digunakan, orang yang bekerja, maupun makanan yang akan dihasilkan (Ali, et al., 2018). Materi pelatihan meliputi cara pembuatan tepung mocaf menggunakan fermentasi M-Bio. Pelatihan diberikan secara demonstrasi dengan menyertakan keterlibatan aktif semua peserta pelatihan. Setelah tepung mocaf jadi atau tersedia dilanjutkan dengan praktek pembuatan produk turunan berbahan baku tepung mocaf antara lain :

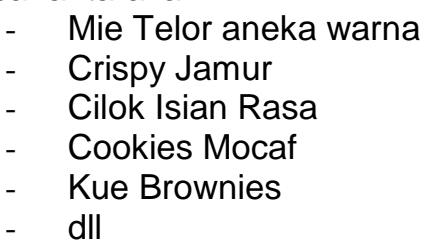

\subsection{Evaluasi}

Bentuk evaluasi dalam kegiatan ini adalah dengan melakukan penilaian terhadap tingkat pemahaman dan keterampilan peserta tentang teknologi pembuatan tepung mocaf, kreatifitas membuat aneka olahannya dan analisis keuntungan usaha.

langka atau sulit didapat, masyarakat mengolah singkong menjadi makanan sebagai pengganti nasi. Selain sumber kalori singkong juga mengandung protein, lemak, hidrat arang, 
kalsium, fosfor, zat besi, serta vitamin B dan vitamin C.

Saat ini singkong dapat ditingkatkan nilai sosial dan ekonominya melalui tepung singkong yang terlebih dahulu telah difermentasi dan dikenal dengan tepung mocaf. Kata MOCAF adalah singkatan dari Modified Cassava Flour yang berarti tepung singkong yang dimodifikasi. MOCAF adalah produk tepung dari singkong (Manihot esculenta Crantz) yang diproses menggunakan prinsip memodifikasi sel singkong secara fermentasi, melalui mikrobia BAL (Bakteri Asam Laktat) yang mendominasi selama fermentasi tepung singkong tersebut.

Mikroba yang tumbuh menghasilkan enzim pektinolitik dan sellulolitik yang dapat menghancurkan dinding sel singkong, sedemikian rupa sehingga terjadi liberasi

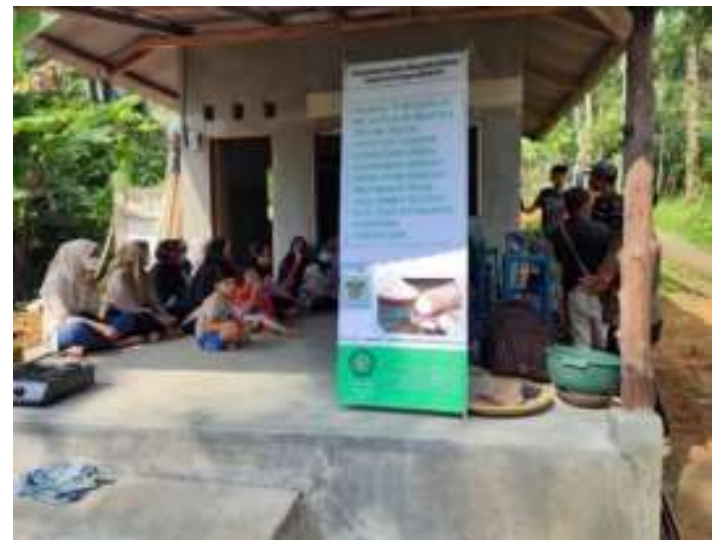

granula pati. Mikroba tersebut juga menghasilkan enzim-enzim yang menghidrolisis pati menjadi gula dan selanjutnya mengubahnya menjadi asam-asam organik, terutama asam laktat. Hal ini akan menyebabkan perubahan karakteristik dari tepung yang dihasilkan berupa naiknya viskositas, kemampuan gelasi, daya rehidrasi, dan kemudahan melarut. Demikian pula, cita rasa MOCAF menjadi netral dengan menutupi cita rasa singkong sampai $70 \%$.

Sosialisasi produksi tepung MOCAF kepada Kelompok Tani Insan Mandiri dan Kelompok Pemberdayaan Kesejahteraan Keluarga (PKK) Desa Setiawaras, Kecamatan Cibalong, Kabupaten Tasikmalaya dianggap mampu meningkatkan masyarakat untuk memproduksi tepung MOCAF.

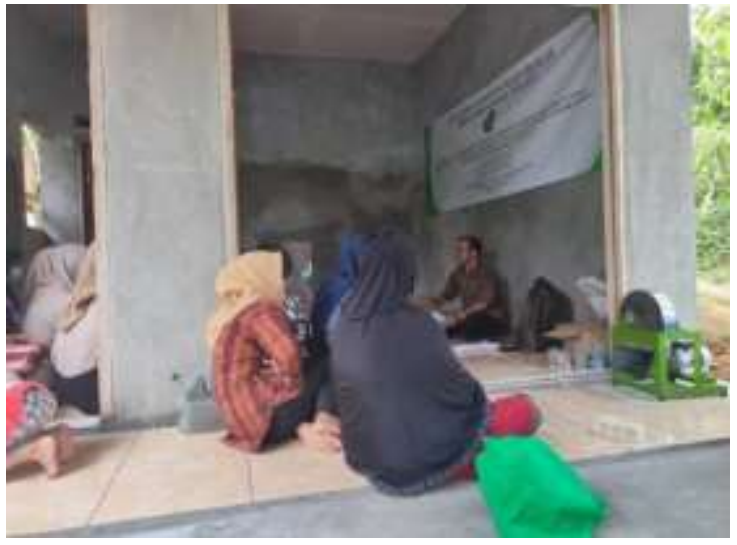

\section{Gambar 1.Sosialisasi/Penyuluhan Produksi Tepung MOCAF}

\begin{abstract}
Setelah kegiatan penyuluhan dilanjutkan dengan kegiatan pelatihan pembuatan MOCAF, adapun proses pembuatan tepung Mocaf adalah sebagai berikut:
\end{abstract}

1) Cuci bersih singkong agar tanah atau kotoran tidak menempel

2) Singkong dikupas dan lapisan kulit singkong yang berwarna cokelat di buang, umbinya sebaiknya direndam dalam air untuk mencegah perubahan warna.

3) Setelah dikupas dan bersih, singkong di iris tipis-tipis sebesar $2-3 \mathrm{~cm}$

4) Rendam singkong dalam larutan Enzim (M Bio) dengan dosis 5-10 ml/liter air. Seluruh bagian singkong harus terendam, rendam selama $7 \mathrm{~s} / \mathrm{d} 12$ jam,
5) Angkat singkong cuci bersih lalu di tiriskan

6) Jemur di terik matahari sampai kering, kadar air 12 - $14 \%$, biasanya memakan waktu 2 - 3 hari, alas penjemuran bisa menggunakan nyiru, terpal atau anyaman bambu.

7) Setelah kering irisan singkong digiling dengan mesin penepung, bisa menggunakan penepung beras atau bisa juga ditumbuk.

8) Lalu gunakan ayakan penyaring dengan saringan 60 mesh agar butiran tepung lebih halus.

9) Selesai, tepung siap digunakan untuk berbagai macam kebutuhan. 

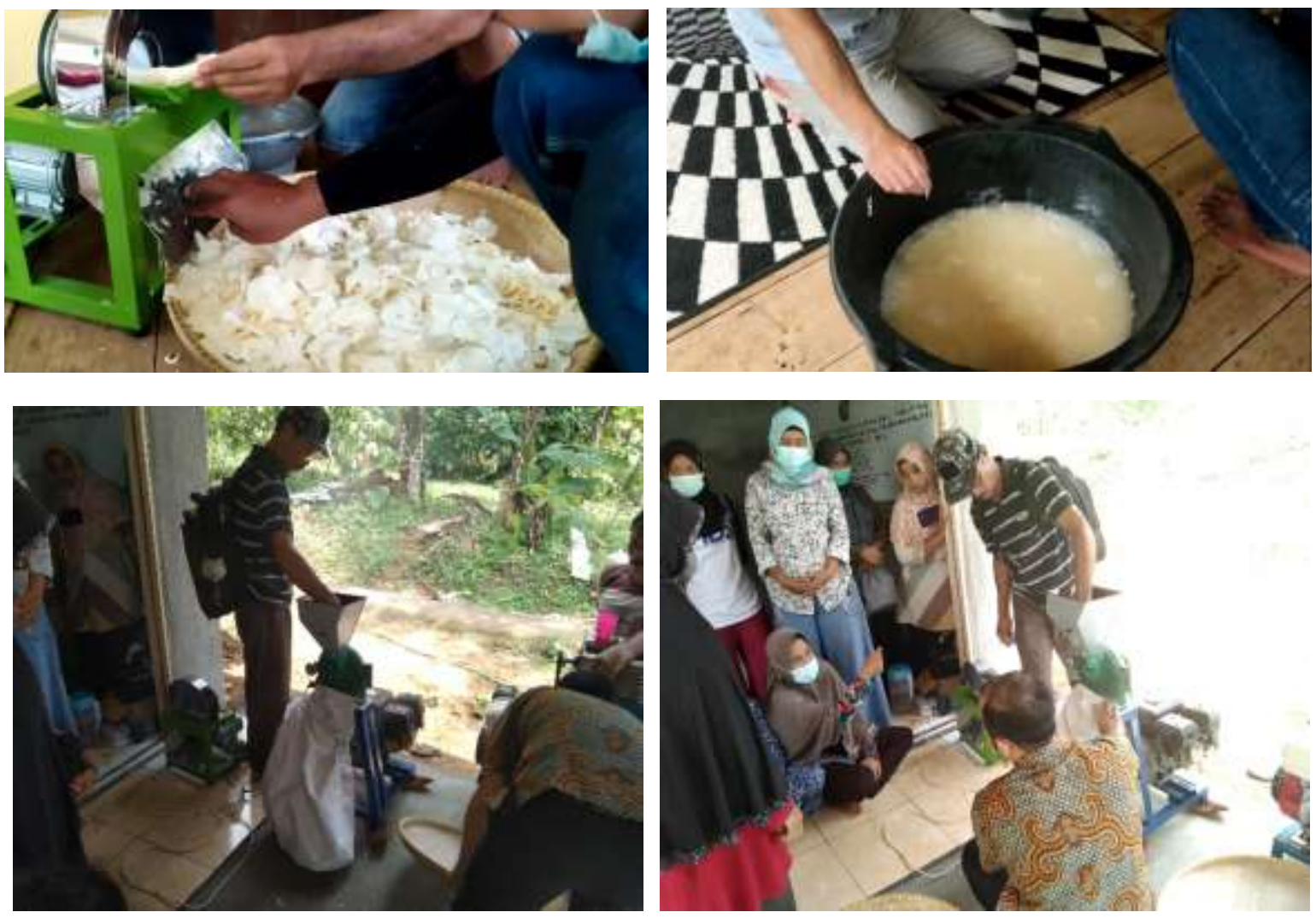

Gambar 2. Proses pengirisan, fermentasi, penggilingan singkong yang akan dijadikan tepung MOCAF

Setelah tepung MOCAF berhasil diproduksi, selanjutnya adalah pembuatan aneka olahan makanan menggunakan tepung MOCAF tersebut. MOCAF bisa digunakan sebagai pengganti dan atau campuran terigu untuk pembuatan crispy jamur, cilok, dan mie mocaf.
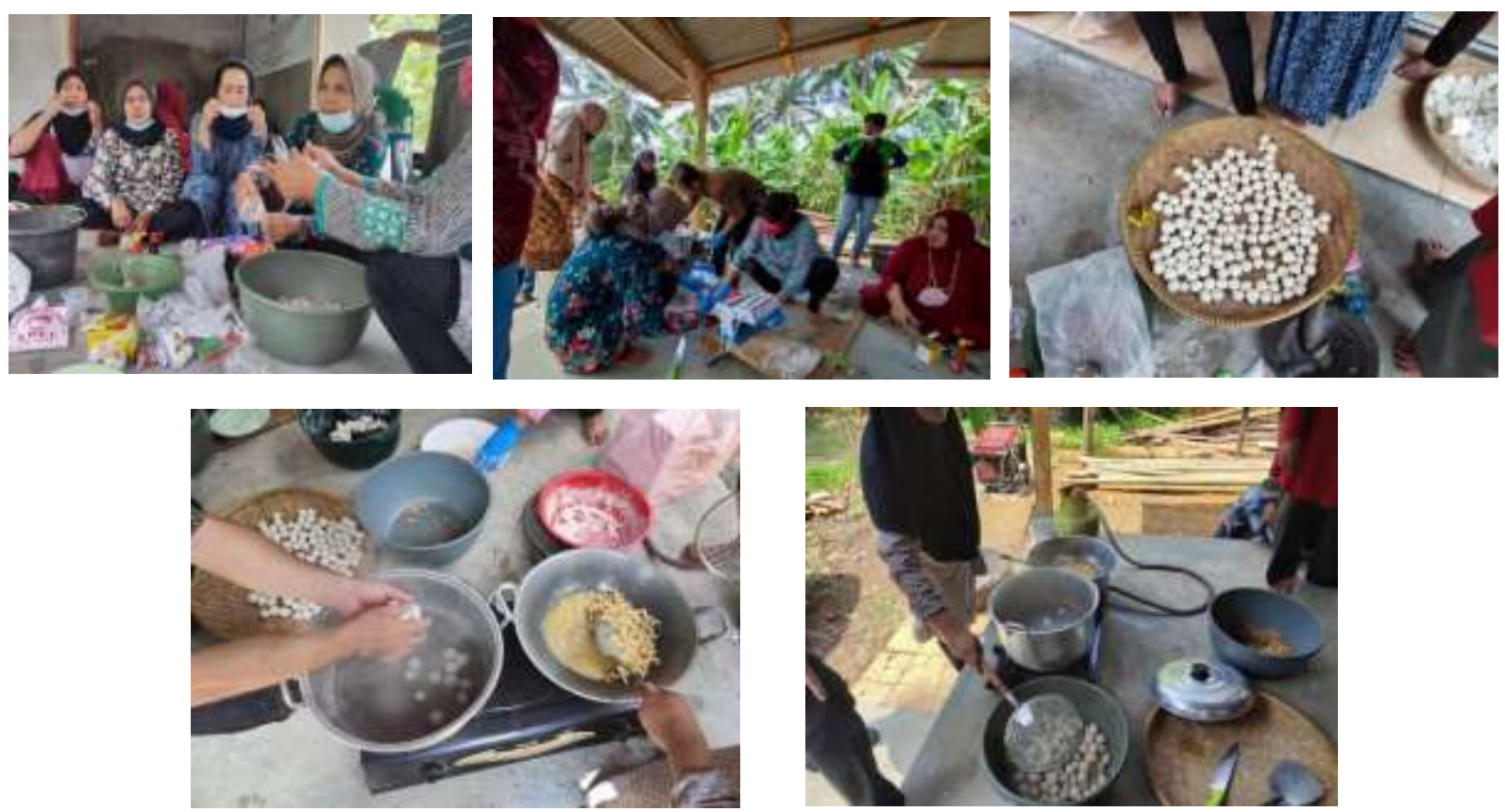

Gambar 3. Pelatihan Pembuatan Olahan Makanan dengan tepung Mocaf 


\section{CILOK MOCAF}

Bahan :

- $1 \mathrm{~kg}$ tepung tapioka

- 250 gram tepung terigu mocaf

- 4 sendok teh garam

- 1 sendok teh penyedap

- 2 batang daun seledri/bawang daun, diiris halus

- 1 liter air, dididihkan

Cara Membuat :

1. Campur tepung tapioka, tepung mocaf, kaldu ayam, garam, dan seledri/bawang daun. Aduk rata.

2. Tuang air panas sedikit-sedikit sambil diuleni hingga tercampur rata.

3. Ambil sedikit adonan lalu bentuk bulat.

4. Rebus di dalam air yang sudah dididihkan hingga matang lalu angkat.

\section{CRISPY JAMUR MOCAF}

Bahan :

- $1 \mathrm{~kg}$ jamur

- $1 \mathrm{~kg}$ minyak goreng

- $\quad 1 / 2$ tepung mocaf

- 1 penyedap rasa

- 1 siung bawang putih

- 1 sendok makan Garam

- 1 sendok teh merica

Cara membuat :

1. Potong jamur bagian batang dan daunya, lalu cuci bersih

2. Tumbuk halus garam, penyedap, bawang putih, merica kemudian tambahkan air

3. Masukan jamur pada bumbu, angkat lalu guling - guling pada tepung mocaf dan goreng

4. Setelah matang, angkat dan tiriskan

5. Crispy jamur mocaf siap saji

\section{COOKIES MOCAF}

Bahan :

100 gram tepung terigu

100 gram tepung mokaf 100 gram gula halus

- 160 gram mentega

- 24 gram susu bubuk

- 1 gram baking powder

- $\quad 40$ gram telur ( 1 butir kecil)

Cara membuat :

1. Gula halus, mentega, telur dimixer hingga homogen (tercampur)

2. Masukkan tepung terigu, tepung mokal, susu bubuk, baking powder ke dalam adonan yang sudah dimixer menggunakan solet sampai rata.

3. Cetak di atas loyang
4. Oven dengan suhu $1600 \mathrm{C}$ sampai matang selama 20 menit.

\section{BROWNIES PANGGANG MOCAF}

Bahan :

- Margarin $200 \mathrm{~g}$

- Air $75 \mathrm{~g}$

- Gula $400 \mathrm{~g}$

- Chocolate dark compound $500 \mathrm{~g}$

- Telur 5 butir

- Mocaf $200 \mathrm{~g}$

- Tepung terigu protein sedang $140 \mathrm{~g}$

- Baking powder $2.5 \mathrm{~g}$

- Coklat bubuk $10 \mathrm{~g}$

Cara membuat :

1. Panaskan margarine, air dan gula hingga mendidih

2. Cincang chocolate dark, masukkan ke dalam mangkuk mixer

3. Tuangkan campuran (margarin, air dan gula) ke dalam coklat, kemudian kocok dengan kecepatan rendah hingga coklat larut

4. Masukkan telur ke dalam adonan di atas secara bertahap hingga tercampur rata

5. Ayak tepung, baking powder dan coklat bubuk, masukkan ke dalam adonan

6. Tuang ke dalam loyang, taburi dengan kenari

7. Oven dengan suhu 150 derajat Celcius selama 50 menit

\section{UCAPAN TERIMAKASIH}

Ucapan terima kasih disampaikan kepada pihak-pihak yang telah membantu dalam kegiatan ini baik moril maupun materil, khususnya warga masyarakat Desa Setiawaras dan Lembaga Penelitian, Pengabdian Masyarakat dan Penjaminan Mutu Pendidikan Universitas Siliwangi.

\section{SIMPULAN DAN SARAN}

Adapun simpulan dari kegiatan pengabdian pada masyarakat ini yaitu:

1) Terjadi peningkatan minat dan keterampilan

2) Peserta bisa memproduksi tepung mocaf dan aneka olahan makanannya.

3) Terjadinya peningkatan pendapatan masyarakat pada masa pandemi covid-19.

Kedepan perlu adanya keberlanjutan kegiatan pemberdayaan masyarakat untuk pendampingan promosi dan penjualan produk. 
DAFTAR PUSTAKA

Ali, F., A, R. L., \& N, R. J. (2018). Cassava Processing into Mocaf Flour and Combro Chips in Pucungbedug Farmers. Jurnal Pengabdian Masyarakat Borneo, 2(2), 44-51.

Amanu, F. N., \& Susanto, W. H. (2014). MOCAF Production in Madura ( Study of Varieties and Plantation Sites ) Toward Quality and Yield. Jurnal Pangan Dan Agroindustri, 2(3), 161-169.

Jensen, S., Skibsted, L. H., Kidmose, U., \& Thybo, A. K. (2015). Addition of cassava flours in bread-making: Sensory and textural evaluation. LWT - Food Science and Technology, 60(1), 292-299. https://doi.org/10.1016/j.Iwt.2014.08.037

Kusumayanti, H., Handayani, N. A., \& Santosa, H. (2015). Swelling Power and Water Solubility of Cassava and Sweet Potatoes Flour. Procedia Environmental Sciences, 23(Ictcred 2014), 164-167. https://doi.org/10.1016/j.proenv.2015.01. 025

Obadina, A. O., Oyewole, O. B., \& Odusami, A. O. (2009). Microbiological safety and quality assessment of some fermented cassava products (lafun, fufu, gari). Scientific Research and Essays, 4(5), 432-435.

Putri, A. E. V. T., Pratjojo, W., \& Susatyo, E. B. (2015). Uji Proksimat Dan Organoleptik Brownies Dengan Substitusi Tepung Mocaf (Modified Cassava Flour). Indonesian Journal of Chemical Science, 4(3).

Rosmeri, V. I., \& Monica, B. N. (2013). Pemanfaatan Tepung Umbi Gadung ( Dioscorea hispida Dennst ) dan Tepung MOCAF ( Modified Cassava Flour ) Sebagai Bahan Substitusi dalam Pembuatan Mie Basah, Mie Kering, dan Mie Instan. Teknologi Kimia Dan Industri, 2(2), 246-256.

Welirang, F. (2011). An Overview Of The Indonesian Eheat Flour Industry. Melbourne. 